The International Indigenous Policy Journal

\title{
Is Geographical Isolation Associated with Poorer Outcomes for Northern Manitoba First Nation Communities?
}

\author{
Josée G. Lavoie, Wanda Phillips-Beck, Kathi Avery Kinew, Stephanie Sinclair, \\ Grace Kyoon-Achan et Alan Katz
}

Volume 12, numéro 1, 2021

URI : https://id.erudit.org/iderudit/1075652ar

DOI : https://doi.org/10.18584/iipj.2021.12.1.10475

Aller au sommaire du numéro

Éditeur(s)

Scholarship@Western (Western University)

ISSN

1916-5781 (numérique)

Découvrir la revue

Citer cet article

Lavoie, J., Phillips-Beck, W., Avery Kinew, K., Sinclair, S., Kyoon-Achan, G. \& Katz, A. (2021). Is Geographical Isolation Associated with Poorer Outcomes for Northern Manitoba First Nation Communities? The International Indigenous Policy Journal, 12(1), 1-22. https://doi.org/10.18584/iipj.2021.12.1.10475

\section{Résumé de l'article}

This study tested the assumption that geographical isolation is associated with poorer population health outcomes among First Nations in Manitoba. Our results show higher premature mortality rates (PMR) in northern communities, declining slower than for any other Manitoba communities. Our results also show lower ambulatory care sensitive conditions (ACSC) hospitalization rate in the North, suggesting barriers to prevention and early diagnosis. There remains a large gap in ACSC hospitalization rates between First Nations and all Manitobans. Further research is warranted to understand the relationship between the changes in the rates of ACSC and the difference in the rates between northern and southern communities.
Copyright ( ) Josée G. Lavoie, Wanda Phillips-Beck, Kathi Avery Kinew, Stephanie Sinclair, Grace Kyoon-Achan, Alan Katz, 2021
Ce document est protégé par la loi sur le droit d'auteur. L'utilisation des services d’Érudit (y compris la reproduction) est assujettie à sa politique d'utilisation que vous pouvez consulter en ligne.

https://apropos.erudit.org/fr/usagers/politique-dutilisation/ 
Volume 12 | Issue 1

January 2021

\section{Is Geographical Isolation Associated with Poorer Outcomes for Northern Manitoba First Nation Communities?}

Josée G. Lavoie

University of Manitoba, Canada, josee.lavoie@umanitoba.ca

Wanda Phillips-Beck

First Nations Health and Social Secretariat of Manitoba, Canada, wphillis-beck@fnhssm

Kathi Avery Kinew

First Nations Health and Social Secretariat of Manitoba, Canada, kathikinew@gmail.com

Stephanie Sinclair

First Nations Health and Social Secretariat of Manitoba, Canada, ssinclair@fnhssm.com

Grace Kyoon-Achan

University of Manitoba, Canada, Grace.KyoonAchan@umanitoba.ca

Alan Katz

University of Manitoba,Canada, Alan_Katz@cpe.umanitoba.ca

Recommended Citation

Lavoie, J. G., Phillips-Beck, W., Kinew, A. K., Sinclair, S., Kyoon-Achan, G., \& Katz, A. (2020). Is geographical isolation associated with poorer outcomes for northern Manitoba First Nation communities? The International Indigenous Policy Journal, 12(1). doi: https://doi.org/10.18584/iipj.2021.12.1.10475 


\title{
Is Geographical Isolation Associated with Poorer Outcomes for Northern Manitoba First Nation Communities?
}

\begin{abstract}
This study tested the assumption that geographical isolation is associated with poorer population health outcomes among First Nations in Manitoba. Our results show higher premature mortality rates (PMR) in northern communities, declining slower than for any other Manitoba communities. Our results also show lower ambulatory care sensitive conditions (ACSC) hospitalization rate in the North, suggesting barriers to prevention and early diagnosis. There remains a large gap in ACSC hospitalization rates between First Nations and all Manitobans. Further research is warranted to understand the relationship between the changes in the rates of ACSC and the difference in the rates between northern and southern communities.
\end{abstract}

\section{Keywords}

Primary care, primary health care, Aboriginal, Indigenous, First Nations, avoidable hospitalizations, mental health, chronic conditions, geography, remoteness

\section{Acknowledgments}

We would like to acknowledge the unique and invaluable contribution of our community partners: Birdtail Sioux Dakota Nation, Berens River First Nation, Cross Lake Band of Indians Pimicikamak Cree Nation, Ebb and Flow First Nation, Northlands Denesuline First Nation, Pinaymootang First Nation, and Fisher River Cree Nation.

This study was funded by the Canada Institutes of Health Research, Grant \# TT1-128267. The funder played no role in the design of the study and collection, analysis, and interpretation of data, and in writing the manuscript.

\section{Creative Commons License} (c) $(1) \Theta 9$

This work is licensed under a Creative Commons Attribution-Noncommercial-No Derivative Works 4.0 License. 


\section{Is Geographical Isolation Associated with Poorer Outcomes for Northern Manitoba First Nation Communities?}

The Truth and Reconciliation Commission of Canada acknowledged that addressing jurisdictional disputes, ensuring sustainable funding, and recognizing the value of "[Indigenous $]^{1}$ healing practices" (p. 163) are key measures to improving the health and social outcomes of Indigenous Peoples in Canada. It called upon all levels of government to acknowledge that the current state of Indigenous health in Canada is a direct result of previous Canadian government policies and put forward 94 Calls to Action to address these issues (Truth and Reconciliation Commission of Canada, 2015).

Previous studies have reported higher rates of avoidable hospitalizations, poorer health outcomes, and shorter life expectancy among First Nation peoples compared to other Canadians (Green et al., 2013; Lavoie et al., 2010; Lyons et al., 2014; Ospina et al., 2015; Riediger et al., 2015). A recent study conducted in Manitoba showed that the inequity gap is widening (Katz et al., 2019).

It is a common assumption that communities located at significant distances from urban centres, where physician services and secondary care are available, have worse health outcomes compared to communities that are located closer to care. This problematic assumption is largely based on an expectation that local services delivery, often managed by First Nations themselves, are likely substandard and/or create additional barriers to care (National Advisory Committee on SARS and Public Health, 2003), and that geographical barriers to access healthcare and other services provided off reserve is a major detriment to the health of First Nations. At times, "traditionalism" (an assumption that northern communities have experienced less colonial disruption and hold values that align more readily with their cultural past) is hinted at as being partially to blame for poorer outcomes. This assumption, however, remains empirically untested.

In the Canadian context, it is important to understand the role of the federal government in the delivery of health services to First Nation communities. Constitutionally, healthcare is the responsibility of provincial governments. Since the formation of a federal health department in 1919, the federal government assumed greater responsibility for the provision of health and curative services in First Nation communities (Lavoie, 2018) primarily to segregate First Nation peoples and protect settler populations from "contagions" assumed to be carried by First Nation peoples (Lux, 2016). Since the 1950s, this has resulted in the development of federally funded health services on reserve. These include nursing stations delivering a limited scope of primary healthcare (PHC) services, and smaller health offices or health centres in communities that can, at least theoretically, access health services off reserve in close-by communities (Health Canada \& First Nations and Inuit Health Branch [FNIHB], 2012). A more detailed description of these models is provided in Table 1.

\footnotetext{
${ }^{1}$ The Commission used the word Aboriginal to align with the terminology embedded in federal policy. The term includes First Nations, Métis, and Inuit. More recently, the term Indigenous has become the preferred terminology and is replacing the word Aboriginal in policy and practice. We opted to use the word Indigenous throughout the article for clarity when referring to all three identity groups.
} 
Table 1. Health Facility Designation Criteria

\begin{tabular}{|c|c|c|c|c|c|c|c|c|}
\hline \multirow[b]{2}{*}{$\begin{array}{l}\text { Type of } \\
\text { facility }\end{array}$} & \multicolumn{2}{|c|}{$\begin{array}{c}\text { Number of } \\
\text { communities }\end{array}$} & \multicolumn{5}{|c|}{ Community characteristics (the community should meet a majority of the following criteria) } & \multirow[b]{2}{*}{$\begin{array}{c}\text { Federally funded health services } \\
\text { available in the community }\end{array}$} \\
\hline & $\begin{array}{l}\text { Across } \\
\text { Canada } \\
\end{array}$ & Manitoba & $\begin{array}{l}\text { On-reserve } \\
\text { population }\end{array}$ & $\begin{array}{l}\text { Level of } \\
\text { isolation }\end{array}$ & Proximity of health services & Access & $\begin{array}{c}\text { Community } \\
\text { infrastructure }\end{array}$ & \\
\hline $\begin{array}{l}\text { No on- } \\
\text { reserve } \\
\text { facility }\end{array}$ & 130 & 2 & $\begin{array}{c}\text { Generally, less } \\
\text { than } 300\end{array}$ & $\begin{array}{l}\text { Non-isolated, } \\
\text { or at close } \\
\text { proximity to a } \\
\text { federal nursing } \\
\quad \text { station }\end{array}$ & $\begin{array}{l}\text { Access to PHC is through a } \\
\text { provincial point of care, often } \\
\text { located close to the community }\end{array}$ & Year-round roads & Variable & None \\
\hline $\begin{array}{l}\text { Health } \\
\text { office }\end{array}$ & 61 & 24 & $\begin{array}{l}0 \text { to } 750 \text { total } \\
\text { on-reserve } \\
\text { population }\end{array}$ & $\begin{array}{l}\text { Non-isolated or } \\
\text { semi-isolated } \\
\text { (or isolated } \\
\text { depending on } \\
\text { road access) }\end{array}$ & $\begin{array}{l}\text { Hospital accessible by road in less } \\
\text { than two hours }\end{array}$ & $\begin{array}{l}\text { All weather road or } \\
\text { air access }\end{array}$ & $\begin{array}{l}\text { Adequate } \\
\text { community } \\
\text { services }\end{array}$ & $\begin{array}{l}\text { Part-time, often non-resident } \\
\text { nursing staff } \\
\text { Screening and prevention } \\
\text { services only }\end{array}$ \\
\hline $\begin{array}{l}\text { Health } \\
\text { station }\end{array}$ & 136 & 0 & Over 100 & $\begin{array}{l}\text { Remote- } \\
\text { isolated or } \\
\text { semi-isolated }\end{array}$ & $\begin{array}{l}\text { Over } 150 \mathrm{~km} \text { from a service centre } \\
\text { but within } 50 \mathrm{~km} \text { of a nursing } \\
\text { station or other federally funded } \\
\text { facility. Hospital accessible by road } \\
\text { in less than two hours }\end{array}$ & $\begin{array}{l}\text { Accessible by air or } \\
\text { road from a federal } \\
\text { facility, poor road } \\
\text { conditions }\end{array}$ & $\begin{array}{l}\text { Limited } \\
\text { community } \\
\text { services }\end{array}$ & $\begin{array}{l}\text { Part-time, often non-resident } \\
\text { nursing staff } \\
\text { Screening and prevention } \\
\text { services only }\end{array}$ \\
\hline $\begin{array}{l}\text { Health } \\
\text { centre }\end{array}$ & 204 & 11 & Over 100 & $\begin{array}{l}\text { Non-isolated or } \\
\text { semi-isolated }\end{array}$ & $\begin{array}{l}\text { Hospital accessible by road in less } \\
\text { than two hours, occasional } \\
\text { unavailability of local ambulance } \\
\text { and first response services }\end{array}$ & $\begin{array}{l}\text { All weather road or } \\
\text { air access, poor } \\
\text { road conditions }\end{array}$ & $\begin{array}{l}\text { Limited } \\
\text { community } \\
\text { services }\end{array}$ & $\begin{array}{l}\text { Emergency, screening, and } \\
\text { prevention services available five } \\
\text { days per week, with limited or no } \\
\text { after-hours care locally }\end{array}$ \\
\hline $\begin{array}{l}\text { Nursing } \\
\text { station }\end{array}$ & 75 & 22 & Over 500 & $\begin{array}{l}\text { Remote or } \\
\text { isolated }\end{array}$ & $\begin{array}{l}\text { Nearest hospital more than two } \\
\text { hours away, limited availability of } \\
\text { local ambulance and first response } \\
\text { services }\end{array}$ & $\begin{array}{l}\text { No year-round } \\
\text { road access to } \\
\text { other healthcare } \\
\text { facilities }\end{array}$ & $\begin{array}{l}\text { Limited } \\
\text { community } \\
\text { services }\end{array}$ & $\begin{array}{l}\text { Local access to screening, } \\
\text { prevention, emergency care, and } \\
\text { treatment services on a } 24 / 7 \text { basis } \\
\text { PHC delivered by primary care } \\
\text { nurses with an expanded scope of } \\
\text { practice, community health nurses, } \\
\text { and paramedical staff }\end{array}$ \\
\hline
\end{tabular}

Note. Sources: Health Canada \& FNIHB, 2003; Lavoie et al., 2005 
It is important to note that federal funding does not cover family physician and specialist care, which are provided free of charge to all Canadians, including First Nations, by provincial healthcare systems. In some communities, on-reserve services are supplemented by visiting physician services (Lavoie et al., 2020). Elsewhere, physician care is accessed off reserve. In addition, provincial health systems provide a variety of preventive and supportive health services to which, theoretically, First Nations living on reserve can access to the same extent as their provincial counterparts. In reality, however, jurisdictional confusion remains, resulting in substantial gaps in services (The Jordan's Principle Working Group, 2015; Lavoie et al., 2015), which perpetuates distrust, differential access to care, and health inequities.

Manitoba has 63 First Nation communities. Although these communities are located along rivers that were once vibrant traditional economic centres, colonial economic development undermined and displaced these economic centres, shifting the seat of economic decision-making away from those communities to southern locales, thereby entrenching and perpetuating systems of economic marginalization (Lavoie, Boyer, \& Kornelsen, 2018; Lavoie, Kornelsen, et al., 2016). Of these First Nations, 22 are now considered "isolated" and most have no permanent road access. These 22 northern First Nation communities access PHC on reserve through a nursing station, while most First Nations in the south operate health centre and health office models with funding from the federal government (Lavoie et al., 2010; Martens et al., 2005).

In this study, the performance of the healthcare system serving First Nation peoples living in southern (non-isolated and semi-isolated) and northern (isolated and remote-isolated) First Nation communities was represented by the rates of episode of hospitalization for ambulatory care sensitive conditions (ACSC) and the length of hospital stay (LOS) for these conditions. ACSC are defined as diseases or conditions that are unlikely to lead to hospitalization if managed in a timely and effective manner through PHC services (Billings et al., 1993).

Hospitalization for ACSC is a very well recognized tool to measure access to PHC services (Gao et al., 2014; Lavoie et al., 2010; Ricketts et al., 2001; Rosano et al., 2013; Van Loenen et al., 2016; Van Loenen, et al., 2014). Several studies have reported that higher rates of ACSC indicate barriers to PHC services (Busby et al., 2015; Lavoie et al., 2010; Lavoie, Ward, et al., 2018; Longman et al., 2015). We have previously used these indicators to identify gaps in the delivery of $\mathrm{PHC}$ and provided recommendations to policymakers to transform the healthcare system within these communities (Lavoie et al., 2010,2011, 2019; Lavoie, Ward, et al., 2018). We acknowledge that hospitalizations are linked to diagnoses and referrals: Rates of hospitalization may be lower when conditions remain undiagnosed as a result of barriers to PHC, potentially resulting in premature mortality. Rates may also be lower as a result of early diagnosis and effective management in PHC. To discern between these two potential explanations, we have argued elsewhere that rates of hospitalization for ACSC should be used in tandem with premature mortality rates (Lavoie et al., 2019).

\section{Methods}

\section{Partnership}

The Innovation Supporting Transformation in Community-Based Primary Healthcare Research Project (iPHIT) is a five-year partnership between university-based researchers from the University of Manitoba, the First Nations Health and Social Secretariat of Manitoba, and eight First Nation 
communities in Manitoba, which range from non-isolated to remote communities and are served by health offices, health centres, or nursing stations. The overall objective of this innovative, strengthsbased program of research is to expand our knowledge of various models of $\mathrm{PHC}$ in rural, remote, and First Nation communities, and to learn from First Nation and rural and remote communities who have developed effective community based PHC.

\section{Source of Data}

We used administrative health data (1984-2014) from the Manitoba Population Research Data Repository housed at the Manitoba Centre for Health Policy, University of Manitoba. The Repository is a comprehensive collection of administrative, registry, survey, and other data that includes the vast majority of residents of Manitoba including residents of First Nation communities. The data used for this study included vital statistics files, the population health registry file for the provincial insured population, the hospital discharge abstract, and census data files. The study included all Manitoba residents eligible to receive health benefits under the Manitoba Health Services Insurance Plan. Six-digit postal codes were used to identify the population associated with each community. Registered members of First Nation communities represent $96.6 \%$ of the overall on-reserve population, others are non-Status (who may be First Nation children not eligible for registration as "Indians" under the Indian Act), Métis, or non-Indigenous individuals who depend on the same services (Lavoie et al., 2010, 2019). ${ }^{2}$ Ethical approvals for this study were received from the University of Manitoba Health Research Ethics Board and data access approval from the Government of Manitoba Health Information Privacy Committee, and both ethical approval and data access from the Manitoba First Nations Health Information Research Governance Committee (HIRGC).

\section{Variables}

Table 2 provides definitions of the dependent variables. We used two dependent variables in this study: episodes of hospital care for ACSC and LOS. We used a previously created definition for ACSC, which is based on the Canadian Institute for Health information (2006) and the Victorian Government Department of Human Resources (Ansari et al., 2002), adapted for Manitoba First Nations to align with their epidemiological profile (Lavoie et al., 2010). We then expanded this definition to add mental health-related ACSC, to align with Manitoba First Nations' concept of PHC (Kyoon-Achan et al., 2019). The categories of ACSC explored in this study are shown in Table 3. Overall, 29 ACSC were defined using three-, four-, and five-digit International Statistical Classification of Disease codes (ICD-9CM and ICD-10-CM), which enabled cross-sectional and longitudinal comparison of hospitalization rates among communities.

\footnotetext{
${ }^{2}$ All data used for this analysis are protected under the privacy policies of the Manitoba Centre for Health Policy, and within the terms of the institutional review board approval for this study and are not publicly available. The datasets generated and/or analyzed during the current study are not publicly available due privacy and confidentiality issues.
} 
Measure of hospitalization

Rates of hospital care episodes

Rates of length of stay per admission

\section{Definition of hospitalization measure}

The discrete number of hospitalization episodes from admission to discharge. Hospitalizations were treated as a single episode when readmission to another hospital occurred within one day, to account for transfers from one hospital to another.

An average of the number of days in hospital for each episode of care.

Table 3. Categories of Ambulatory Care Sensitive Conditions (ACSC) Explored

\section{Categories of ACSC}

Chronic conditions

Acute conditions

Mental health

Vaccine preventable conditions

All ACSC

\section{Conditions}

Diabetes; diabetes with complications; hypertension; asthma; acute bronchitis; chronic obstructive pulmonary disease; pneumonia; epilepsy; angina, heart failure and pulmonary edema; iron deficiency anemia

Dental conditions; cellulitis; severe ear, nose, and throat infections

Schizophrenia and mood disorder

Hepatitis A and B; influenza; hemophilic influenza; measles; mumps; rubella; meningitis; tuberculosis; tetanus; poliomyelitis; pertussis

All conditions combined

Our main independent variable was isolation level as reflected by the location of the community (south or north of the $53^{\text {rd }}$ parallel). There is no single, universally accepted definition of concepts such as rural and remote. Most definitions generally focus on geography, population density, or access to services such as healthcare (Lavoie, Wong, et al., 2016; Wakerman, 2004). The "right" definition is context dependent. For our analysis, the First Nation communities on the eastern side of Lake Winnipeg in Manitoba were grouped together with those above the $53^{\text {rd }}$ parallel due to their isolation from any major urban centre. This breakdown is based on our collective in-depth knowledge of these communities' access to care, and on federal indexes of isolation, which take into consideration federal services 
provided on reserve (Health Canada \& FNIHB, 2012). Some indexes misrepresent First Nations' reality. For example, Statistics Canada's recent set of remoteness and accessibility indices shows northern Manitoba First Nation communities as having no access to health services (Alasia et al., 2017), where other resources, which reflect our collective experience of these communities, show them as having access to services delivered in nursing stations and generally better health outcomes than southern First Nation communities with access to provincial services within driving distance (Lavoie et al., 2010). For this article, we defined First Nation communities as those recognized as Indian Reserves under the Indian Act.

For the purpose of this study, we included under the variable non-First Nation rural communities all Manitoba communities with a population of less than $8,000(n=183)$ because all First Nation communities in Manitoba have fewer than 8,000 residents. We then divided communities into southern and northern communities. Southern and northern labels were attached to communities where members normally reside, and not to the location of their care experience. Table 4 shows the population in each category.

Table 4. Population per Category of Community

\begin{tabular}{lcc}
\hline & \multicolumn{2}{c}{ Average } \\
\cline { 2 - 3 } & $\mathbf{1 9 8 4 - 1 9 8 8}$ & $\mathbf{2 0 1 0 - 2 0 1 4}$ \\
\hline First Nation northern Manitoba & 27,051 & 41,418 \\
First Nation southern Manitoba & 27,948 & 32,425 \\
Non-First Nation rural Manitoba & 365,727 & 393,061 \\
All Manitoba & $1,055,061$ & $1,186,947$ \\
\hline
\end{tabular}

\section{Data Analysis}

Data was analyzed using generalized estimating equation (GEE) models, controlling for age, sex, and socioeconomic status with postal codes used as an ecological measure using census data, to identify differences and trends in hospitalization rates for ACSC and LOS. GEEs are used as a method for analyzing correlated longitudinal data. Trends in rates of ACSC hospitalization and LOS by residents living on First Nation reserves were identified from 1984 to 2014. Observations with a missing value for the model variables (e.g., age, sex, socioeconomic status) were excluded from the analysis. The structure of the working correlation matrix used to model the correlation of the responses from subjects was exchangeable (or compound symmetry). Because of the relatively small sample size, we used a rolling five-year average to increase the number of episodes of care, as a five-year average is more stable than single-year data for comparisons. 


\section{Results}

\section{Premature Mortality Rates (PMR)}

Table 5 shows that between 2005 and 2014, the average PMR was significantly higher for First Nations living in northern ( 7.27 deaths per 1,000 occurring in those between 0 and 75 years of age) or southern contexts (5.92), compared to non-First Nation rural communities (2.95) and all of Manitoba (3.26). We note that the PMR for northern First Nations is slightly higher than for southern First Nations. We also note that the PMR has been declining in both northern (1.25\%) and southern First Nations (1.40\%), albeit at a much slower rate when compared to Manitoba non-First Nation rural communities (4.62\%) and all of Manitoba (3.51\%). All differences are statistically significant.

Table 5. Comparison of Premature Mortality Rate (PMR), 2005-2014

\begin{tabular}{|c|c|c|c|c|c|}
\hline & $\begin{array}{l}\text { Adjusted } \\
\text { PMR rate }\end{array}$ & $\begin{array}{l}\text { Probability that } \\
\text { PMR is different } \\
\text { from } \\
\text { All Manitoba } \\
\text { (p-value) }\end{array}$ & Direction & $\begin{array}{c}\text { Percentage } \\
\text { change }\end{array}$ & $p$-value \\
\hline $\begin{array}{l}\text { First Nation northern } \\
\text { Manitoba }\end{array}$ & $\begin{array}{c}7.27 \\
(6.92-7.62)\end{array}$ & $.00^{*}$ & Decreasing & 1.25 & $.0494^{*}$ \\
\hline $\begin{array}{l}\text { First Nation southern } \\
\text { Manitoba }\end{array}$ & $\begin{array}{c}5.92 \\
(5.62-6.23)\end{array}$ & $.00^{*}$ & Decreasing & 1.40 & $.0177^{*}$ \\
\hline $\begin{array}{l}\text { Non-First Nation rural } \\
\text { Manitoba }\end{array}$ & $\begin{array}{c}2.95 \\
(2.89-3.01)\end{array}$ & $.00^{*}$ & Decreasing & 4.62 & $<.0001^{*}$ \\
\hline All Manitoba & $\begin{array}{c}3.26 \\
(3.23-3.29)\end{array}$ & & Decreasing & 3.51 & $<.0001^{*}$ \\
\hline
\end{tabular}

Note. The PMR is the age- and sex-adjusted average annual premature mortality rates, which is the number of deaths per 1,000 occurring in those between 0 and 75 years of age.

\section{Hospitalization Rates for All (Combined) ACSC}

Table 6 and Figure 1 show that, between 1984 and 2014, First Nation peoples living in southern communities had significantly higher hospitalization rates for all ACSC (313.69 in 1984-1988; 105.23 in 2010-2014) compared to northern First Nation communities (189.32 in 1984-1988; 94.17 in 20102014) and all Manitoba ( 85.90 in 1984-1988; 36.24 in 2010-2014). The hospitalization rates for these ACSC decreased by $2.29 \%$ during the same period in northern First Nation communities, by $4.41 \%$ in southern First Nation communities, by $3.08 \%$ in non-First Nation rural communities, and by $3.77 \%$ in all Manitoba. These results were statistically significant. 
Table 6. Age-, Sex-, and Socioeconomic Status-Adjusted Hospitalization Rates for Ambulatory Care Sensitive Conditions (ACSC) per 1,000 Population, 1986-2014

\begin{tabular}{|c|c|c|c|c|c|c|c|}
\hline & \multicolumn{2}{|c|}{ 1984-1988 } & \multicolumn{2}{|c|}{$2010-2014$} & \multicolumn{3}{|c|}{$1984-2014$} \\
\hline & Rate & $\begin{array}{c}p \text {-value } \\
\text { (compared to } \\
\text { All Manitoba) }\end{array}$ & Rate & $\begin{array}{c}p \text {-value } \\
\text { (compared to } \\
\text { All Manitoba) }\end{array}$ & Direction & $\%$ change & $p$-value \\
\hline \multicolumn{8}{|l|}{ All ACSC } \\
\hline First Nation northern Manitoba & $\begin{array}{c}189.32 \\
(158.56-226.05)\end{array}$ & $.0000^{*}$ & $\begin{array}{c}94.17 \\
(70.77-125.32)\end{array}$ & $.00^{*}$ & Decreasing $^{\mathrm{a}}$ & 2.29 & $<.0001^{*}$ \\
\hline First Nation southern Manitoba & $\begin{array}{c}313.69 \\
(259.07-379.84)\end{array}$ & $.0000^{*}$ & $\begin{array}{c}105.23 \\
(79.20-139.79)\end{array}$ & $.00^{*}$ & Decreasing ${ }^{\mathrm{b}}$ & 4.41 & $<.0001^{*}$ \\
\hline Non-First Nation rural Manitoba & $\begin{array}{c}111.29 \\
(96.23-128.71)\end{array}$ & $.0005^{*}$ & $\begin{array}{c}39.58 \\
(30.47-51.42)\end{array}$ & .51 & Decreasing $^{\mathrm{c}}$ & 3.77 & $<.0001^{*}$ \\
\hline All Manitoba & $\begin{array}{c}85.90 \\
(61.35-120.27)\end{array}$ & & $\begin{array}{c}36.24 \\
(35.90-36.58)\end{array}$ & & Decreasing $^{\mathrm{d}}$ & 3.08 & $<.0001^{*}$ \\
\hline \multicolumn{8}{|l|}{ Chronic ACSC } \\
\hline First Nation northern Manitoba & $\begin{array}{c}75.85 \\
(59.50-96.70)\end{array}$ & $.0000^{*}$ & $\begin{array}{c}44.30 \\
(34.90-56.24)\end{array}$ & $.00^{*}$ & Decreasing $^{a}$ & 2.37 & $<.0001^{*}$ \\
\hline First Nation southern Manitoba & $\begin{array}{c}112.42 \\
(88.30-143.13)\end{array}$ & $.0000^{*}$ & $\begin{array}{c}65.13 \\
(52.92-80.15)\end{array}$ & $.00^{*}$ & Decreasing ${ }^{\mathrm{b}}$ & 2.84 & $<.0001^{*}$ \\
\hline Non-First Nation rural Manitoba & $\begin{array}{c}49.77 \\
(41.05-60.35)\end{array}$ & .0871 & $\begin{array}{c}20.56 \\
(17.542-24.27)\end{array}$ & .10 & Decreasing $^{c}$ & 3.60 & $<.0001^{*}$ \\
\hline All Manitoba & $\begin{array}{c}42.07 \\
(32.50-54.44)\end{array}$ & & $\begin{array}{c}17.85 \\
(17.61-18.09)\end{array}$ & & Decreasing $^{\mathrm{d}}$ & 3.56 & $<.0001^{*}$ \\
\hline
\end{tabular}


Table 6. Age-, Sex-, and Socioeconomic Status-Adjusted Hospitalization Rates for Ambulatory Care Sensitive Conditions (ACSC) per 1,000 Population, 1986-2014 (continued)

\begin{tabular}{|c|c|c|c|c|c|c|c|}
\hline & \multicolumn{2}{|c|}{ 1984-1988 } & \multicolumn{2}{|c|}{$2010-2014$} & \multicolumn{3}{|c|}{$1984-2014$} \\
\hline & Rate & $\begin{array}{c}p \text {-value } \\
\text { (compared to } \\
\text { All Manitoba) }\end{array}$ & Rate & $\begin{array}{c}p \text {-value } \\
\text { (compared to } \\
\text { All Manitoba) }\end{array}$ & Direction & $\%$ change & $p$-value \\
\hline \multicolumn{8}{|l|}{ Acute ACSC } \\
\hline First Nation northern Manitoba & $\begin{array}{c}55.22 \\
(45.85-66.50)\end{array}$ & $.0000^{*}$ & $\begin{array}{c}10.98 \\
(7.19-16.76)\end{array}$ & $.00^{*}$ & Decreasing $^{\mathrm{a}}$ & 5.91 & $<.0001^{*}$ \\
\hline First Nation southern Manitoba & $\begin{array}{c}76.61 \\
(61.87-94.86)\end{array}$ & $.0000^{*}$ & $\begin{array}{c}13.52 \\
(8.72-20.97)\end{array}$ & $.00^{*}$ & Decreasing $^{\mathrm{b}}$ & 6.41 & $<.0001^{*}$ \\
\hline Non-First Nation rural Manitoba & $\begin{array}{c}24.69 \\
(21.22-28.73)\end{array}$ & $.0010^{*}$ & $\begin{array}{c}6.09 \\
(4.10-9.03)\end{array}$ & .50 & Decreasing $^{c}$ & 4.42 & $<.0001^{*}$ \\
\hline All Manitoba & $\begin{array}{c}19.13 \\
(12.60-29.04)\end{array}$ & & $\begin{array}{c}5.31 \\
(5.18-5.44)\end{array}$ & & Decreasing $^{\mathrm{d}}$ & 4.62 & $<.0001^{*}$ \\
\hline \multicolumn{8}{|l|}{ Mental health ACSC } \\
\hline First Nation northern Manitoba & $\begin{array}{c}10.38 \\
(7.39-14.57)\end{array}$ & .2210 & $\begin{array}{c}29.58 \\
(18.97-46.11)\end{array}$ & $.00^{*}$ & Increasing $^{\mathrm{a}}$ & 5.49 & $<.0001^{*}$ \\
\hline First Nation southern Manitoba & $\begin{array}{c}14.95 \\
(11.23-19.91)\end{array}$ & .2933 & $\begin{array}{c}21.22 \\
(13.66-32.96)\end{array}$ & $.01^{*}$ & Increasing $^{\mathrm{b}}$ & 1.52 & $.0153^{*}$ \\
\hline Non-First Nation rural Manitoba & $\begin{array}{c}14.10 \\
(11.16-17.82)\end{array}$ & .4277 & $\begin{array}{c}9.87 \\
(6.67-14.61)\end{array}$ & .30 & Decreasing $^{c}$ & 0.72 & $.0007^{*}$ \\
\hline All Manitoba & $\begin{array}{c}12.83 \\
(7.82-21.03)\end{array}$ & & $\begin{array}{c}12.14 \\
(11.94-12.33)\end{array}$ & & Increasing $^{\mathrm{d}}$ & 0.07 & .9533 \\
\hline
\end{tabular}


Table 6. Age-, Sex-, and Socioeconomic Status-Adjusted Hospitalization Rates for Ambulatory Care Sensitive Conditions (ACSC) per 1,000 Population, 1986-2014 (continued)

\begin{tabular}{|c|c|c|c|c|c|c|c|}
\hline & \multicolumn{2}{|c|}{$1984-1988$} & \multicolumn{2}{|c|}{$2010-2014$} & \multicolumn{3}{|c|}{$1984-2014$} \\
\hline & Rate & $\begin{array}{c}p \text {-value } \\
\text { (compared to } \\
\text { All Manitoba) }\end{array}$ & Rate & $\begin{array}{c}p \text {-value } \\
\text { (compared to } \\
\text { All Manitoba) }\end{array}$ & Direction & $\%$ change & $p$-value \\
\hline \multicolumn{8}{|l|}{ Vaccine preventable ACSC } \\
\hline & $\begin{array}{c}12.73 \\
(10.47-15.47)\end{array}$ & $.0000^{*}$ & $\begin{array}{c}8.32 \\
(5.58-12.39)\end{array}$ & $.00^{*}$ & Decreasing $^{\mathrm{a}}$ & 1.00 & .1317 \\
\hline & $\begin{array}{c}14.38 \\
(11.56-17.88)\end{array}$ & $.0000^{*}$ & $\begin{array}{c}1.87 \\
(1.87-1.18)\end{array}$ & $.01^{*}$ & Decreasing $^{\mathrm{b}}$ & 8.08 & $<.0001^{*}$ \\
\hline & $\begin{array}{c}5.91 \\
(5.10-6.85)\end{array}$ & $.0000^{*}$ & $\begin{array}{c}0.81 \\
(0.60-1.11)\end{array}$ & .23 & Decreasing $^{\mathrm{c}}$ & 7.57 & $<.0001^{*}$ \\
\hline & $\begin{array}{c}4.36 \\
(3.06-6.21)\end{array}$ & & $\begin{array}{c}0.98 \\
(0.98-1.04)\end{array}$ & & Decreasing $^{\mathrm{d}}$ & 6.27 & $<.0001^{*}$ \\
\hline
\end{tabular}

${ }^{a}$ First Nation northern Manitoba slope differs from 0.

${ }^{b}$ First Nation southern Manitoba slope differs from 0 .

${ }^{c}$ Non-First Nation rural Manitoba slope differs from 0 .

${ }^{\mathrm{d}}$ All Manitoba 0 slope differs from 0. 


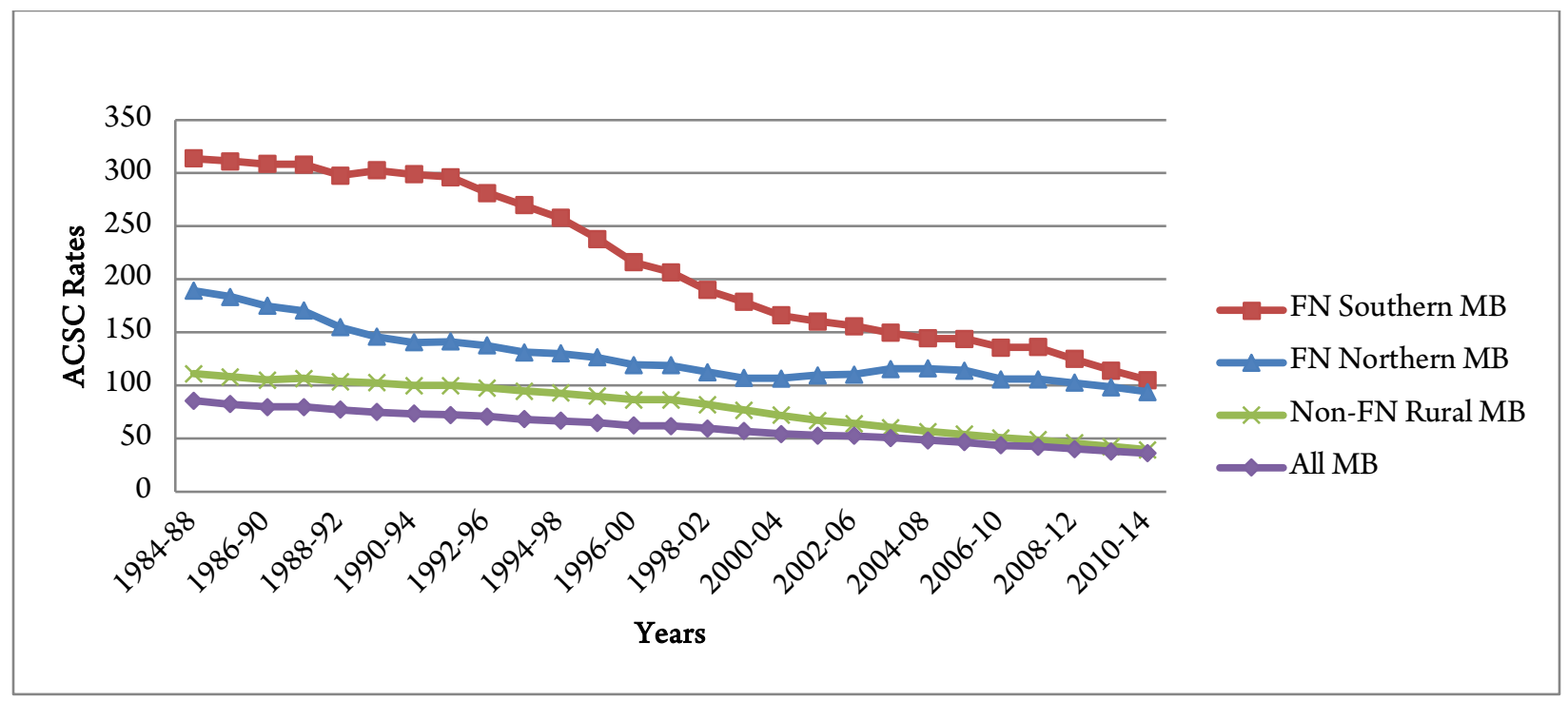

Figure 1. Age- and socioeconomic status-adjusted ambulatory care sensitive conditions (ACSC) rates for all ACSC (per 1,000 population). FN is First Nations. MB is Manitoba.

\section{Hospitalization Rates for Acute and Chronic ACSC}

The hospitalization rates for chronic (Table 6 and Figure 2) and acute (Table 6 and Figure 3) ACSC were higher in southern (chronic ACSC 112.42 per 1,000 in 1984-1988 and 65.13 in 2010-2014; acute ACSC 76.61 in 1984-1988 and 13.52 in 2010-2014) and northern First Nation communities (chronic ACSC 75.85 per 1,000 in 1984-1988 and 44.30 in 2010-2014; acute ACSC 55.22 in 1984-1988 and 10.98 in 2010-2014) compared to all Manitoba $(p<.0001)$. However, the hospitalization rates for these conditions (acute and chronic) were higher in southern First Nation communities compared to northern First Nations. Between 1984 and 2014, the rate of decline for acute conditions was $6.41 \%$ in southern First Nation communities and 5.91\% in northern First Nation communities. The rate of decline for chronic conditions was $2.84 \%$ in the southern First Nation communities and $2.37 \%$ in the northern First Nation communities.

\section{Hospitalization Rates for Vaccine Preventable ACSC}

For vaccine preventable ACSC (Table 6 and Figure 4), the rates were higher in northern (12.73 per 1,000 in 1984-1988; 8.32 in 2010-2014) compared to southern First Nation communities (14.38 per 1,000 in 1984-1988; 1.87 in 2010-2014; $p<.0001$ ). Between 1984 and 2014, the hospitalization rates for these conditions did not decline in northern First Nation communities, whereas they declined by $8.08(p<.0001)$ in southern First Nation communities. We conducted a sub-analysis (data not shown) and found the higher rates of hospitalization for these conditions are related to the higher rates of tuberculosis $(\mathrm{TB})$ in northern communities. 


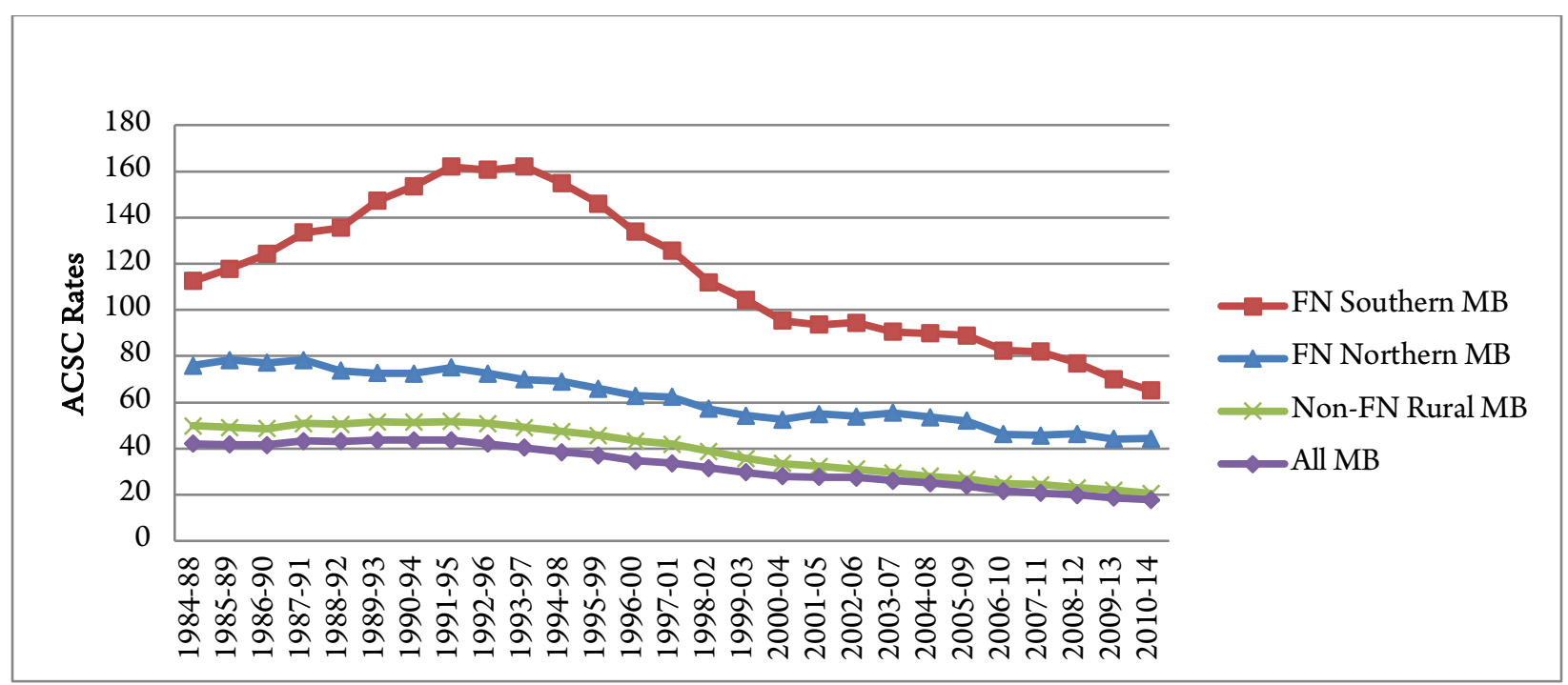

Figure 2. Age-, sex-, and socioeconomic status-adjusted rates for chronic ambulatory care sensitive conditions (ACSC; per 1,000 population). FN is First Nations. MB is Manitoba.

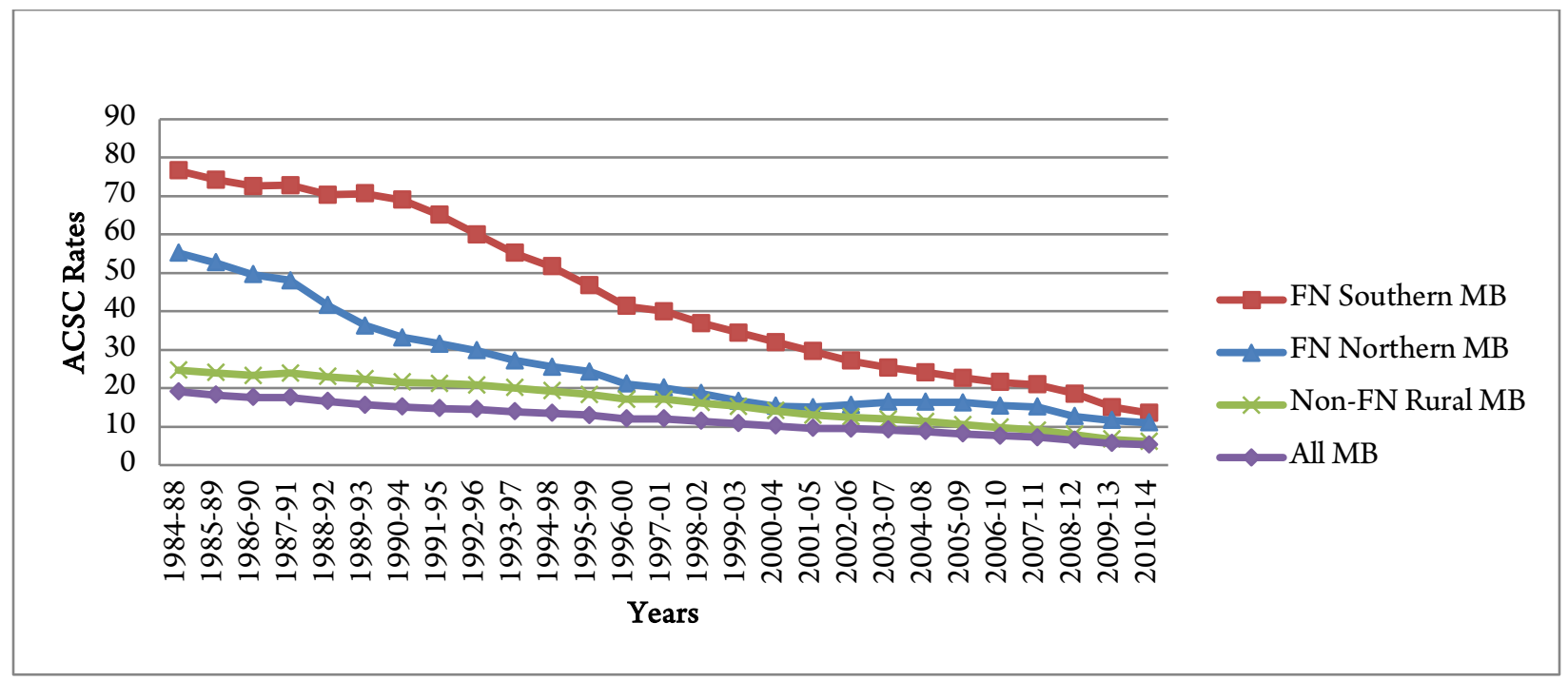

Figure 3. Age-, sex-, and socioeconomic status-adjusted rates of hospitalization for acute ambulatory care sensitive conditions (ACSC; per 1,000 population). FN is First Nations. MB is Manitoba. 


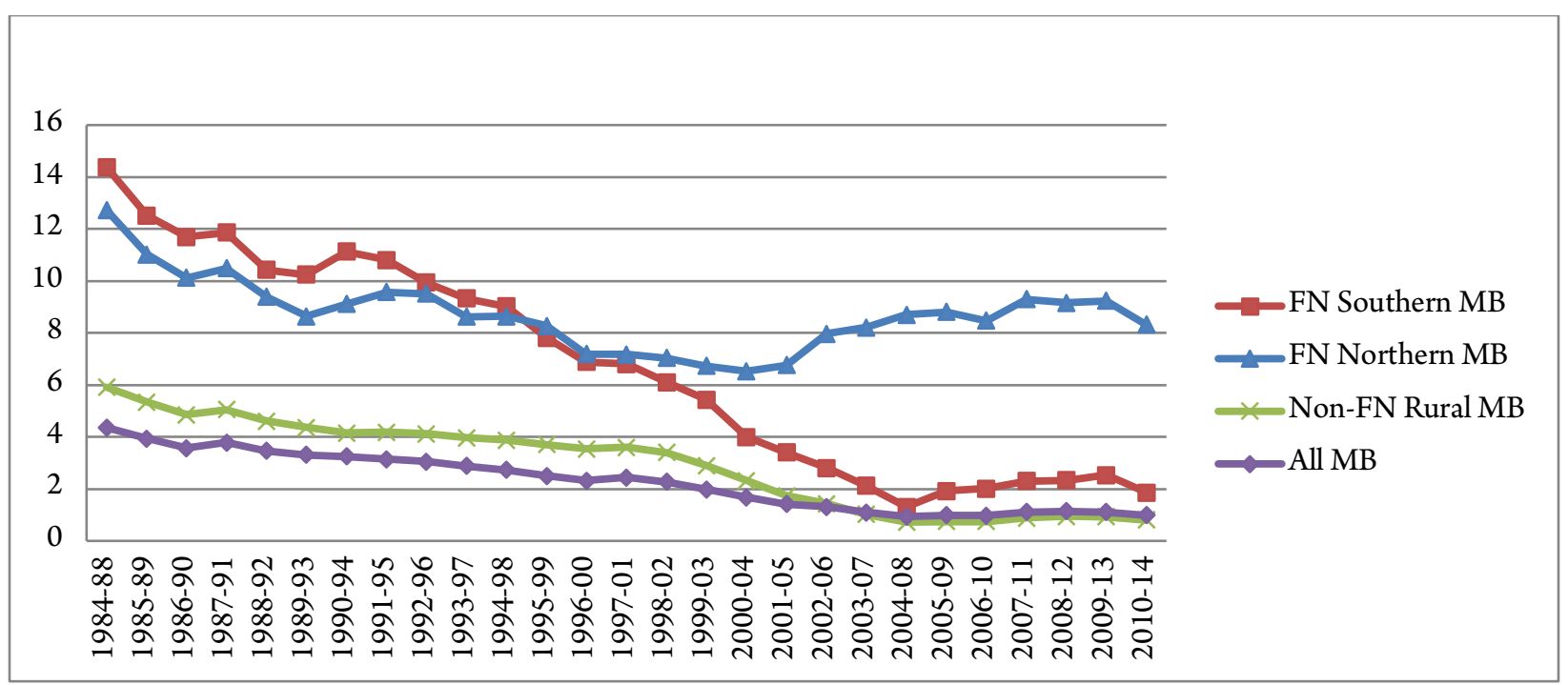

Figure 4. Age-, sex-, and socioeconomic status-adjusted rates of hospitalization for vaccine preventable ambulatory care sensitive conditions (ACSC; per 1,000 population). FN is First Nations. MB is Manitoba.

\section{Mental Health-Related ACSC}

Our data shows that between 1984 and 2014, the hospitalization rates for mental health-related conditions were significantly higher in northern First Nation communities (10.38 per 1,000 in 19841988 ; 29.58 in 2010-2014) compared to southern First Nation communities (14.95 per 1,000 in 1984$1988 ; 21.22$ in 2010-2014; $p<.0001)$. Further, the gaps in rates of hospitalization for mental healthrelated ACSC have continuously widened when compared to all Manitoban and non-First Nation rural communities, increasing between 1984 to 2014 in southern and northern First Nation communities by $1.52 \%(p=.015)$ and $5.49 \%(p<.0001)$, respectively. In comparison, the rates decreased in rural nonFirst Nation areas during the same period.

\section{Length of Stay (LOS)}

The LOS did not change significantly between 1984 and 2014 for acute, chronic, and all ACSC. The exception was for mental health-related conditions, where the LOS increased by $1.67 \%$ only for southern First Nation communities ( $p=.003)$. The LOS for mental health-related ACSC (Figure 5) was consistently significantly shorter for First Nation communities compared to all Manitoba. The LOS for all other ACSC increased significantly for all Manitoba (change $0.63 \%, p=.0011$ ) but not for First Nations. 


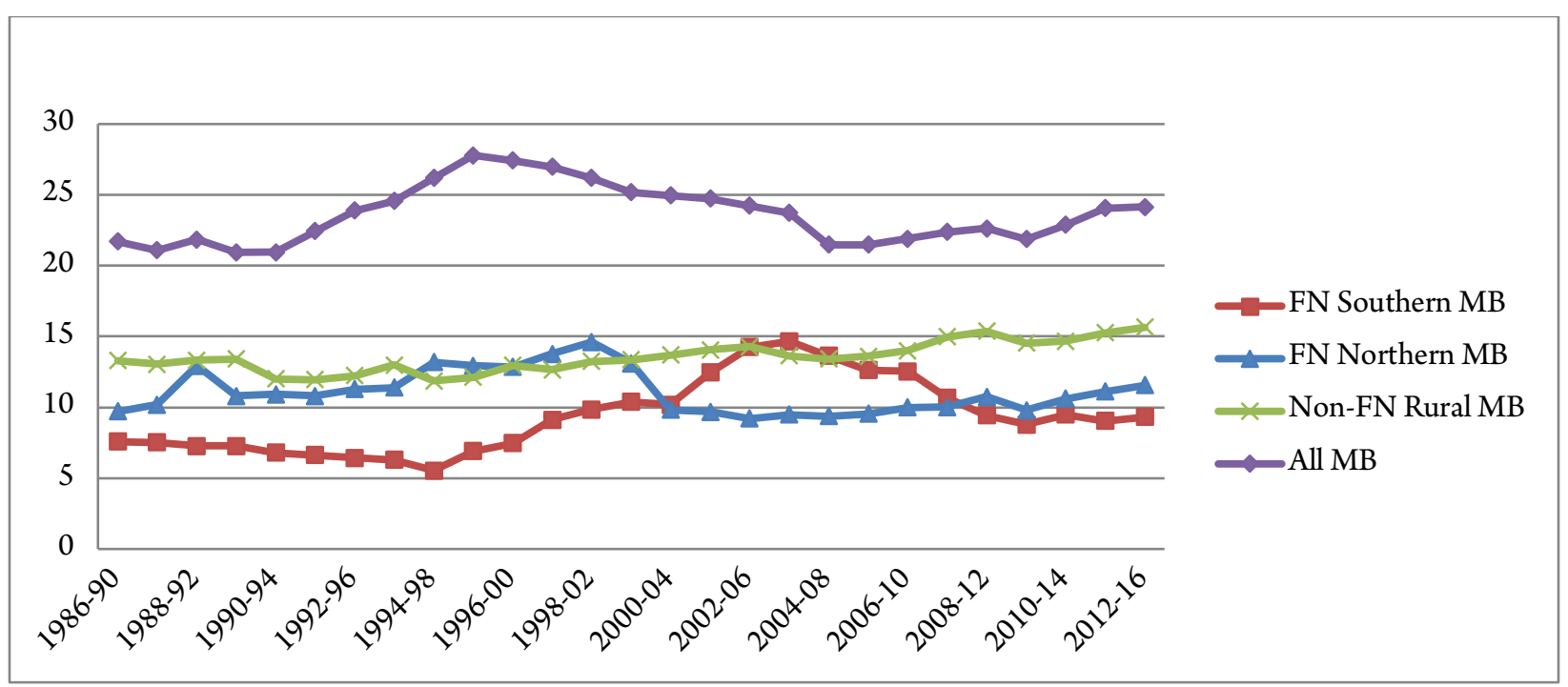

Figure 5. Age-, sex-, and socioeconomic status-adjusted length of stay (LOS) rates for mental health-related ambulatory care sensitive conditions (ACSC). FN is First Nations. MB is Manitoba.

\section{Discussion}

This study sheds light on differences in hospitalization rates for ACSC between southern and northern First Nation communities and compares these rates to all of Manitoba. We show that the hospitalization rates for acute and chronic ACSC are higher in the southern First Nations compared to the northern First Nation communities. The rates are significantly higher in northern and southern First Nation communities compared to all Manitoba. We note that rates are declining along with PMR, suggesting that rates of hospitalization are dropping at least in part due to decreased need for hospitalization. Even though the rates for acute and chronic conditions are decreasing over time in southern and northern First Nation communities, and in all other jurisdictions, it still clearly demonstrates the continuing inequities between all First Nation communities and all other Manitobans.

This study has many strengths. First, the use of administrative healthcare data to assess the performance of rural and remote healthcare systems is innovative and is an effective method to measure the performance of healthcare systems at a fairly low cost. The available data allowed us to run several GEE models and to run separate analyses on acute, chronic, vaccine preventable, and mental health ACSCs, and detect variations between different communities. Second, Indigenous scholars and proponents have advocated for many years for shifting the focus of research to be more responsive to local concerns and to reflect the voice and values of First Nation communities (Smylie \& Anderson, 2006). This involves, first and foremost, developing a respectful, ethical relationship with First Nations and determining what is important to them. The reported results are just one study from a large collaborative project (the iPHIT as described above). The overall objective of this innovative, strength-based program of research is to learn about PHC in rural, remote, and First Nation communities and learn from First Nation communities about their innovation in developing effective community-based PHC. The iPHIT project 
involved First Nations in every aspect of the research process (Kyoon-Achan, Lavoie, et al., 2018, 2019; Kyoon-Achan, Philips-Beck, et al., 2018).

We acknowledge that this study has limitations. First, we recognize that our definition of mental healthrelated ACSC is limited because current administrative data cannot reliably identify conditions such as post-traumatic stress disorder (PTSD) or mental health-related substance misuse. Second, the hospitalization rates for ACSC do not reflect the quality of acute care and supportive services in the community, delays in diagnosis, or medical transportation issues in First Nation communities (Lavoie et al., 2015). Also, the study does not control for many social determinants of health. However, it is important to note that the southern and the northern First Nation communities we are comparing encounter very similar challenges, such as lack of local infrastructure, which includes unavailability of clean water, inadequate housing, and limited access to services and opportunities, as a result of common federal policies (Lavoie, 2018). Finally, the study does not report on community-based programs available in any of the First Nation communities, and whether there are more effective community-based programs in First Nation communities served with different models of care. However, even when considering these programs, it is clear that the objective of closing the healthcare equity gap is far from having been achieved.

Our results are consistent with a previous study, which reported that First Nation communities in Manitoba that were located close to an urban centre in southern Manitoba had worse health outcomes (defined as higher rates of hospitalization for ACSC; Lavoie et al., 2010) and premature mortality rates (Katz et al., 2019) compared to isolated communities. Lavoie and colleagues (2010) showed that onreserve services provided primarily in nursing stations by nurse practitioners and/or nurses working with an expanded scope of practice are better able to address the needs of those living with chronic and acute conditions compared to the other models of on-reserve care. The nursing station model is the predominant model for providing PHC services in isolated northern First Nation communities. These results suggest that better access to PHC services provided in First Nation communities could be one of the reasons for the observed results. Communities themselves generally also highlight that their continued participation in subsistence economies, use of their language, and practice of their ceremonies are key factors.

PHC is an integral part of the healthcare system of any community, and better access to quality PHC was associated with lower hospitalization for ACSC (Gibson et al., 2013; Starfield et al., 2005). Nevertheless, PHC is not the only determinant of ACSC: The health status of the population, personal and collective resilience, overcrowded houses, coordination of care, geographical location, systematic racism, stigma, and socioeconomic opportunities are all important determinants of health that have been shown to be associated with higher or lower hospitalization rates for ACSC (Gibson et al., 2013; Muenchberger \& Kendall, 2010). Thus, it is extremely important not to ignore the role of social determinants of health in both southern and northern First Nation communities in relation to hospitalization for ACSC.

While this study looked at differences in hospitalization rates based on geographical location, it did not control for all the previously listed determinants of ACSC and all the programs available to residents. There are important variations in the distribution of these social determinants of health across southern and northern First Nation communities (Katz et al., 2019). Crowded houses, poverty, malnutrition, lack 
of access to responsive PHC services, stigma, and lack of culturally appropriate practices are all important factors contributing to the higher rates of hospitalizations (Dehghani et al., 2018). Equitable and culturally appropriate healthcare services in all First Nation communities is only one, albeit important, action to reduce health disparities.

In the current study, the hospitalization rates for mental health-related conditions were higher in First Nation communities compared to the rest of Manitoba. Reports show that First Nation peoples continue to bear a disproportionate burden of physical and emotional illness (Green et al., 2013; Katz et al., 2019; Lavoie et al., 2010; Campbell et al., 2015). In Manitoba, the delivery of mental health services in First Nation communities is fragmented; services are not comprehensive, less accessible, and rarely available on a 24/7 basis (Bombay, 2015; Patel, 2019). This study also shows that the LOS for mental health-related conditions is shorter for First Nation peoples compared to other Manitobans. It is important to note that the results for all Manitoba overrepresent urban-based populations, who are more likely to be hospitalized at higher levels of acuity only. We therefore expect urban-centric data to show longer LOS.

Still, our results could indicate that First Nation peoples are discharged from hospitals before receiving the care they need, and this could result in a revolving door of admission and re-admission for mental healthcare. While a growing impetus to integrate comprehensive mental healthcare into PHC services is occurring globally, integration has been fraught with challenges (Mossialos \& Wenzl, 2016; World Health Organisation, 2008). Challenges vary but are commonly characterized by fiscal constraints, organizational issues, availability of medical technologies and public health surveillance systems, the cultural and technical competence of health professionals working with marginalized groups and urban rural bias (Lavoie, Kornelsen et al., 2016; Spoont et al., 2011; World Health Organisation, 2008). Nevertheless, integrating mental health services into PHC could reduce stigma, improve access to mental healthcare services, and improve social integration (World Health Organisation, 2008). The communities involved in the iPHIT program of research have clearly indicated that from their perspective, mental health is an integral component of all care, including PHC (Kyoon-Achan et al., 2019). These communities integrate PHC and mental health seamlessly using the Medicine Wheel as a model that takes a holistic approach to pursue overall health (Kyoon-Achan, Philips-Beck, et al., 2018).

\section{Conclusion}

The results presented in this article have important implications for health services policy planning and the incorporation of equity perspective to the objectives of health research in First Nation communities. There is a large gap in hospitalization rates for ACSC between First Nations and other Manitobans, and the hospitalization rates for chronic and acute ACSC are higher in the southern rather than the northern (isolated) First Nation communities. However, the hospitalization rates for mental health-related conditions have been increasing since 1984 and are higher in northern compared to southern First Nation communities. Urgent action is needed to address the mental health challenges faced by northern First Nation communities.

Organizational-level interventions to promote the provision of more equitable, responsive, and respectful PHC services for First Nation peoples living on reserves in Manitoba are needed to close the equity gap within this population (Browne et al., 2016). Considerations should be made for policies to 
better support traditional healing practices; while initiatives have emerged (Blignault et al., 2018; Browne et al., 2018; Drost, 2019; Fijal \& Beagan, 2019; Logan et al., 2020), these have been localized and have yet to receive systemic federal support. Also, critical actions are required to address the distribution of resources and the needs of Indigenous Peoples, supporting the Truth and Reconciliation Commission of Canada's Calls to Action, which begins with recognizing and implementing healthcare rights of First Nation peoples as identified in international law, constitutional law, and under the Treaties. Systematic social and health inequities in southern and northern First Nations communities will only be addressed through equitable rights-based funding, equitable access to PHC in each First Nation community, and through active involvement of Indigenous Peoples in Canada in developing long-term structural changes. First Nations' inherent right to self-determination also requires moving their research knowledge into action. Data from this research is important for future program planning to deliver healthcare services in First Nation communities in Manitoba.

The 2015 Truth and Reconciliation Commission report (Truth and Reconciliation Commission of Canada, 2015) urged the federal government to implement Calls to Action 18 and 19, which involves expanding the scope and mandate of health facilities in southern communities to include essential PHC services in all First Nation communities. Access to PHC services is only one measure, improving the living conditions for all First Nations living on reserve, reducing systemic and jurisdictional barriers, addressing racism within the healthcare system, and a coordinated effort by all levels of government will all be necessary to close the gap between First Nations and all other Manitobans (and Canadians).

We believe that our study has important implications for Indigenous communities beyond Manitoba and Canada. Remoteness is often associated with poorer health outcomes. While our study shows that this may be the case for some health conditions, our results show that generalizations are not appropriate. Research that supports a more nuanced understanding of remoteness as a health protective factor and as a factor adding complexity to access to needed services is necessary.

\section{References}

Alasia, A., Bédard, F., Bélanger, J., Guimond, E., \& Penney, C. (2017). Measuring remoteness and accessibility: A set of indices for Canadian communities. https://www150.statcan.gc.ca/ $\underline{\mathrm{n} 1 / \mathrm{pub} / 18-001-\mathrm{x} / 18-001-\mathrm{x} 2017002-\mathrm{eng} . \mathrm{htm}}$

Ansari, Z., Carson, N., Serraglio, A., Barbetti, T., \& Cicuttini, F. (2002). The Victorian Ambulatory Care Sensitive Conditions Study: Reducing demand on hospital services in Victoria. Australian Health Review, 25(2), 71-77. https://doi.org/10.1071/ah020071

Billings, J., Zeitel, L., Lukomnik, J., Carey, T. S., Blank, A. E., \& Newman, L. (1993). Impact of socioeconomic status on hospital use in New York City. Health Affairs, 12(1), 162-173. https://doi.org/10.1377/hlthaff.12.1.162

Blignault, I., Hunter, J., \& Mumford, J. (2018). Integration of Indigenous healing practices with Western biomedicine in Australia, Canada, New Zealand and the United States of America: A scoping 
review protocol. JBI Database of Systematic Reviews and Implementation Reports, 16(6), 1354-1360. https://doi.org/10.11124/jbisrir-2017-003468

Bombay, A. (2015). A call to end mental health disparities for Indigenous people. The Lancet Psychiatry, 2(10), 861-862. https://doi.org/10.1016/s2215-0366(15)00352-1

Browne, A. J., Varcoe, C., Ford-Gilboe, M., Wathen, N., Smye, V., Jackson, B. E., Wallace, B., Pauly, B., Herbert, C. P., Lavoie, J. G., Wong, S., \& Blanchet Garneau, A. (2018). Disruption as opportunity: Impacts of an organizational-level health equity intervention in primary care clinics. International Journal for Equity in Health, 17(1), 154. https://doi.org/ $\underline{10.1186 / \mathrm{s} 12939-018-0820-2}$

Browne, A. J., Varcoe, C., Lavoie, J. G., Smye, V., Wong, S. T., Krause, M., Tu, D., Goodwin, O., Khan, K., \& Fridkin, A. (2016). Enhancing health care equity with Indigenous populations: Evidencebased strategies from an ethnographic study. BMC Health Services Research, 16(544), 16. https://doi.org/10.1186/s12913-016-1707-9

Busby, J., Purdy, S., \& Hollingworth, W. (2015). A systematic review of the magnitude and cause of geographic variation in unplanned hospital admission rates and length of stay for ambulatory care sensitive conditions. BMC Health Services Research, 15, 324. https://doi.org/10.1186/ $\underline{\text { s12913-015-0964-3 }}$

Campbell, R., Martire, J., Upitis, I., Hudon, J., Nelson, K., \& Tremblay, M. (2015). Report 4-Access to health services for remote First Nations communities (2015 spring reports of the Auditor General of Canada). https://www.oag-bvg.gc.ca/internet/English/parl_oag_201504 $\underline{04 \text { e } 40350 . h t m l}$

Canadian Institute for Health Information. (2006). Pan-Canadian primary health care indicators. (Report 1, Volume 1: Pan-Canadian Primary Health Care Indicator Development Project). https://www.cihi.ca/sites/default/files/document/pdf_phc indi_reportlvollfin_en. pdf? ga $=2.20411768 .1152479327 .1611163777-1608162406.1611163777$

Dehghani, K., Lan, Z., Li, P., Michelsen, S. W., Waites, S., Benedetti, A., Lejeune, P., Torrie, J., Robinson, E., Vejvoda, B., Mullah, M., Redwood, D., Cooper, M., Fanning, A., Yacoub, W., Alvarez, G. G., Søborg, B., Long, R., \& Menzies, D. (2018). Determinants of tuberculosis trends in six Indigenous populations of the USA, Canada, and Greenland from 1960 to 2014: A populationbased study. Lancet Public Health, 3(3), e133-e142. https://doi.org/10.1016/s2468$\underline{2667(18) 30002-1}$

Drost, J. L. (2019). Developing the alliances to expand traditional Indigenous healing practices within Alberta Health Services. The Journal of Alternative and Complementary Medicine, 25(S1), S69S77. https://doi.org/10.1089/acm.2018.0387

Fijal, D., \& Beagan, B. L. (2019). Indigenous perspectives on health: Integration with a Canadian model of practice. Canadian Journal of Occupational Therapy, 86(3), 220-231. https://doi.org/ $\underline{10.1177 / 0008417419832284}$ 
Gao, J., Moran, E., Li, Y. F., \& Almenoff, P. L. (2014). Predicting potentially avoidable hospitalizations. Medical Care, 52(2), 164-171. https://doi.org/10.1097/mlr.0000000000000041

Gibson, O. R., Segal, L., \& McDermott, R. A. (2013). A systematic review of evidence on the association between hospitalisation for chronic disease related ambulatory care sensitive conditions and primary health care resourcing. BMC Health Services Research, 13, 336. https://doi.org/10.1186/1472-6963-13-336

Green, M. E., Wong, S. T., Lavoie, J. G., Kwong, J., MacWilliam, L., Peterson, S., Liu, G., \& Katz, A. (2013). Admission to hospital for pneumonia and influenza attributable to 2009 pandemic A/H1N1 influenza in First Nations communities in three provinces of Canada. BMC Public Health, 13, 1029. https://doi.org/10.1186/1471-2458-13-1029

Health Canada \& First Nations and Inuit Health Branch (FNIHB). (2003). Health Facility Classification Policy, working draft.

Health Canada \& First Nations and Inuit Health Branch (FNIHB). (2012). First Nations and Inuit Health Facilities and Capital Program-Cluster evaluation, final report. https://www.canada. ca/en/health-canada/corporate/about-health-canada/accountability-performance-financialreporting/evaluation-reports/first-nations-inuit-health-facilities-capital-program-clusterevaluation.html

The Jordan's Principle Working Group. (2015). Without denial, delay, or disruption: Ensuring First Nations children's access to equitable services through Jordan's Principle. Assembly of First Nations. https://www.afn.ca/uploads/files/jordans principle-report.pdf

Katz, A., Kinew, K. A., Star, L., Taylor, C., Koseva, I., Lavoie, J. G., Burchill, C., Urquia, M. L., Basham, A., Rajotte, L., Ramayanam, V., Jarmasz, J., \& Burchill, S. (2019). The health status of and access to healthcare by Registered First Nation Peoples in Manitoba. http://umanitoba.ca/faculties/ health_sciences/medicine/units/chs/departmental_units/mchp/Landing-FNAtlas.html

Kyoon-Achan, G., Lavoie, J. G., Kinew, K. A., Philips-Beck, W., Ibrahim, N., Sinclair, S., \& Katz, A. (2018). Innovating for transformation in First Nations health using community-based participatory research. Qualitative Health Research, 28(7), 1036-1049. https://doi.org/ $\underline{10.1177 / 1049732318756056}$

Kyoon-Achan, G., Lavoie, J. G., Phillips-Beck, W., Kinew, K. A., Ibrahim, N., Sinclair, S., \& Katz, A. (2019). What changes would Manitoba First Nations like to see in the primary healthcare they receive? A qualitative investigation. Healthcare Policy, 15(2), 85-99. https://doi.org/ $\underline{10.12927 / \text { hcpol.2019.26069 }}$

Kyoon-Achan, G., Philips-Beck, W., Lavoie, J. G., Eni, R., Sinclair, S., Avery Kinew, K., Ibrahim, N., \& Katz, A. (2018). Looking back, moving forward: A culture-based framework to promote mental wellness in Manitoba First Nations communities. International Journal of Culture and Mental Health, 11(4), 679-692. https://doi.org/10.1080/17542863.2018.1556714 
Lavoie, J. G. (2018). Medicare and the care of First Nations, Métis and Inuit. Journal of Health Economics, Policy and Law, 13(3-4), 280-298. https://doi.org/10.1017/s1744133117000391

Lavoie, J. G., Boyer, Y., \& Kornelsen, D. (2018). Patchy and southern-centric: Health policies for northern and Indigenous Canadians. In R. Schiff \& H. Møller (Eds.), Health and healthcare in the Canadian North. UBC Press.

Lavoie, J. G., Forget, E. L., Dahl, M., Martens, P. J., \& O'Neil, J. D. (2011). Is it worthwhile to invest in home care? Healthc Policy, 6(4), 35-48. http://doi.org/10.12927/hcpol.2011.22395

Lavoie, J. G., Forget, E. L., Prakash, T., Dahl, M., Martens, P. J., \& O’Neil, J. D. (2010). Have investments in on-reserve health services and initiatives promoting community control improved First Nations' health in Manitoba? Social Science \& Medicine, 71(4), 717-724. https://doi.org/10.1016/j.socscimed.2010.04.037

Lavoie, J. G., Kaufert, J. M., Browne, A. J., Mah, S., \& O'Neil, J. D. (2015). Negotiating barriers, navigating the maze: First Nation Peoples' experience of medical relocation. Canadian Public Administration, 58(2), 295-314. https://doi.org/10.1111/capa.12111

Lavoie, J. G., Kornelsen, D., Boyer, Y., \& Wylie, L. (2016). Lost in maps: Regionalization and Indigenous health services. Healthcare Papers, 16(1), 63-73. https://doi.org/10.12927/ hcpap.2016.24773

Lavoie, J. G., O'Neil, J. D., Sanderson, L., Elias, B., Mignone, J., Bartlett, J., Forget, E. L., Burton, R., Schmeichel, C., \& McNeil, D. (2005). The evaluation of the First Nations and Inuit health transfer policy. Centre for Aboriginal Health Research. http://publications.gc.ca/collections/ collection_2016/sc-hc/H14-191-2006-eng.pdf

Lavoie, J. G., Phillips-Beck, W., Kinew, K. A., Kyoon-Achan, G., Sinclair, S., \& Katz, A. (2020). The relationship between rates of hospitalization for ambulatory care sensitive conditions and local access to primary healthcare in Manitoba First Nations communities. Canadian Journal of Public Health, 2020. https://doi.org/10.17269/s41997-020-00421-3

Lavoie, J. G., Ward, A. Wong, S. T., Ibrahim, N., Morton, D. O'Neil, J., \& Green, M. (2018). Hospitalization for mental health related ambulatory care sensitive conditions: What are the trends for First Nations Peoples living on-reserve in British Columbia? International Journal for Equity in Health, 17, 156. https://doi.org/10.1186/s12939-018-0860-7

Lavoie, J. G., Wong, S. T., Ibrahim, N., O’Neil, J. D., Green, M., \& Ward, A. (2019). Underutilized and undertheorized: The use of hospitalization for ambulatory care sensitive conditions for assessing the extent to which primary healthcare services are meeting needs in British Columbia First Nation communities. BMC Health Services Research, 19(1), 50. https://doi.org/10.1186/ $\underline{\text { s12913-018-3850-y }}$

Lavoie, J. G., Wong, S., Katz, A., \& Sinclair, S. (2016). Opportunities and barriers to rural, remote and First Nation health services research in Canada: Comparing access to administrative claims data 
in Manitoba and British Columbia. Healthcare Policy, 12(1), 52-58. https://doi.org/10.12927/ $\underline{\text { hcpol.2016.24775 }}$

Logan, L., McNairn, J., Wiart, S., Crowshoe, L., Henderson, R., \& Barnabe, C. (2020). Creating space for Indigenous healing practices in patient care plans. Canadian Medical Education Journal, 11(1), e5-e15. https://doi.org/10.36834/cmej.68647

Longman, J. M., Passey, M. E., Ewald, D. P., Rix, E., \& Morgan, G. G. (2015). Admissions for chronic ambulatory care sensitive conditions-A useful measure of potentially preventable admission? BMC Health Services Research, 15, 472. https://doi.org/10.1186/s12913-015-1137-0

Lux, M. K. (2016). Separate beds: A history of Indian hospitals in Canada, 1920s-980s. University of Toronto Press. https://doi.org/10.3138/9781442663114

Lyons, K. J., Ezekowitz, J. A., Liu, W., McAlister, F. A., \& Kaul, P. (2014). Mortality outcomes among status Aboriginals and Whites with heart failure. Canadian Journal of Cardiolology, 30(6), 619626. https://doi.org/10.1016/j.cjca.2014.03.004

Martens, P. J., Sanderson, D., \& Jebamani, L. (2005). Health services use of Manitoba First Nations people: Is it related to underlying need? Canadian Journal of Public Health, 96 (Suppl. 1), S39S44. https://doi.org/10.1007/bf03405315

Mossialos, E., \& Wenzl, M. (2016). International profiles of health care systems: Australia, Canada, Denmark, England, France, Germany, Italy, Japan, The Netherlands, New Zealand, Norway, Singapore, Sweden, Switzerland, and the United States. https://doi.org/10.15868/ socialsector. 25100

Muenchberger, H., \& Kendall, E. (2010). Predictors of preventable hospitalization in chronic disease: Priorities for change. Journal Public Health Policy, 31(2), 150-163. https://doi.org/10.1057/ jphp.2010.3

National Advisory Committee on SARS and Public Health. (2003). Learning from SARS: Renewal of public health in Canada-A report of the National Advisory Committee on SARS and Public Health October 2003. Health Canada. https://www.canada.ca/en/publichealth/services/reports-publications/learning-sars-renewal-public-health-canada.html

Ospina, M. B., Voaklander, D., Senthilselvan, A., Stickland, M. K., King, M., Harris, A. W., \& Rowe, B. H. (2015). Incidence and prevalence of chronic obstructive pulmonary disease among Aboriginal Peoples in Alberta, Canada. PLoS One, 1O(4). https://doi.org/10.1371/journal.pone.0123204

Patel, A. (2019). Access to mental healthcare in Indigenous communities across Canada. Global Health: Annual Review, 4, 40-43. https://journals.mcmaster.ca/ghar/article/view/2116

Ricketts, T. C., Randolph, R., Howard, H. A., Pathman, D., \& Carey, T. (2001). Hospitalization rates as indicators of access to primary care. Health Place, $7(1), 27-38$. https://doi.org/10.1016/s1353$\underline{8292(00) 00035-6}$ 
Riediger, N. D., Lukianchuk, V., \& Bruce, S. G. (2015). Incident diabetes, hypertension and dyslipidemia in a Manitoba First Nation. International Journal of Circumpolar Health, 74, 27712. https://doi.org/10.3402/ijch.v74.27712

Rosano, A., Loha, C. A., Falvo, R., van der Zee, J., Ricciardi, W., Guasticchi, G., \& de Belvis, A. G. (2013). The relationship between avoidable hospitalization and accessibility to primary care: A systematic review. The European Journal of Public Health, 23(3), 356-360. https://doi.org/ $\underline{10.1093 / \text { eurpub/cks053 }}$

Smylie, J., \& Anderson, M. (2006). Understanding the health of Indigenous Peoples in Canada: Key methodological and conceptual challenges. Canadian Medical Association Journal, 175(6), 602 605. https://doi.org/10.1503/cmaj.060940

Spoont, M., Greer, N., Su, J., Fitzgerald, P., Rutks, I., \& Wilt, T. J. (2011). Rural vs. urban ambulatory health care: A systematic review. Department of Veterans Affairs. https://www.ncbi.nlm.nih.gov/books/NBK56144/pdf/Bookshelf_NBK56144.pdf

Starfield, B., Shi, L., \& Macinko, J. (2005). Contribution of primary care to health systems and health. The Milbank Quarterly, 83(3), 457-502. https://doi.org/10.1111/j.1468-0009.2005.00409.x

Truth and Reconciliation Commission of Canada. (2015). Honouring the truth, reconciling for the future: Summary of the final report of the Truth and Reconciliation Commission of Canada. http://www.trc.ca/assets/pdf/Executive Summary_English_Web.pdf

Van Loenen, T., Faber, M. J., Westert, G. P., \& Van den Berg, M. J. (2016). The impact of primary care organization on avoidable hospital admissions for diabetes in 23 countries. Scandinavian Journal of Primary Health Care, 34(1), 5-12. https://doi.org/10.3109/02813432.2015.1132883

Van Loenen, T., Van den Berg, M. J., Westert, G. P., \& Faber, M. J. (2014). Organizational aspects of primary care related to avoidable hospitalization: A systematic review. Family Practice, 31(5), 502-516. https://doi.org/10.1093/fampra/cmu053

Wakerman, J. (2004). Defining remote health. Australian Journal of Rural Health, 12(5), 210-214. https://doi.org/10.1111/j.1440-1854.2004.00607.x

World Health Organisation. (2008). Integrating mental health into primary care: A global perspective. https://www.who.int/mental_health/policy/services/integratingmhintoprimarycare/en/ 